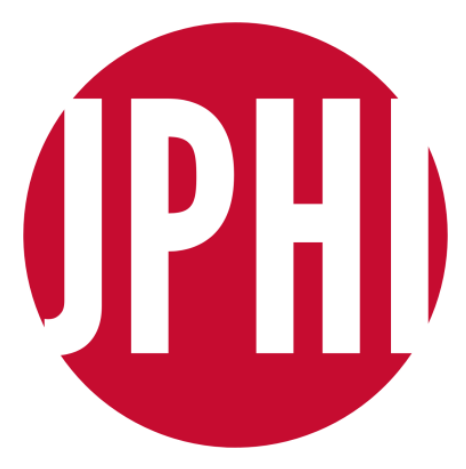

Jurnal Penegakan Hukum Indonesia (JPHI)

\section{Implikasi Isbath Nikah Terhadap Status Istri, Anak Dan Harta Perkawianan Dalam Perkawinan Dibawah Tangan}

\author{
Muhammad Andri
}

Fakultas Hukum Universitas Darul Ulum

J1. K.H Abdurrahman Wahid No 29 A. Jombang

Email: mandri1976@gmail.com

\begin{tabular}{|c|c|}
\hline & Abstract \\
\hline $\begin{array}{l}\text { Editorial Office: } \\
\text { Jl. Brigjen H. Hasan Basri } \\
\text { Komplek Polsek Banjarmasin } \\
\text { Utara Jalur 3, No. } 9 \text { Kota } \\
\text { Banjarmasin; Provinsi } \\
\text { Kalimantan Selatan; Republik } \\
\text { Indonesia (70125). } \\
\text { Email } \\
\text { jphi.scholarcenter@ gmail.com } \\
\text { Principal Contact } \\
+6282157709493\end{array}$ & $\begin{array}{l}\text { Law Number } 1 \text { of } 1974 \text { article } 2 \text { paragraph (2) clearly mandates the } \\
\text { registration of marriages, but the fact is that in the community there are still } \\
\text { marriages that are not recorded, this is evidenced by the existence of } \\
\text { marriage ceremonies in Indonesia such as in the high court of the East Java } \\
\text { religion, which has granted the case. petition (voluntary) for } 679 \text { cases that } \\
\text { were granted according to the performance report of the High Religious } \\
\text { Court in } 2019 \text {. The problem raised is how the implications of marriage isbath } \\
\text { on the status of wife, children and marital assets in an underhand marriage. } \\
\text { The research method in writing this article is a normative legal research } \\
\text { method, which is research that is focused on examining the application of the } \\
\text { norms or norms in positive law. Normative legal research methods are } \\
\text { usually qualitative (not in the form of numbers).In his findings that the } \\
\text { implication of marriage isbath on the status of wife, children and marital } \\
\text { assets in an underhand marriage, that the existence of a marriage certificate } \\
\text { in accordance with Supreme Court Regulation No.1 of } 2015 \text { has legal } \\
\text { consequences if an application is made for legalization of marriage which } \\
\text { implies legal guarantees of husband and wife marital relations, children and } \\
\text { birth certificates, assets in marriage can obtain legal guarantees. } \\
\text { Keywords: isbath of marriage; legality; marital status }\end{array}$ \\
\hline $\begin{array}{l}\text { (C) JPHI } 2020 \\
\text { Licensed under the CC } 4.0 . \\
\text { Creative Commons Attribution- } \\
\text { ShareAlike } 4.0 \text { International } \\
\text { License }\end{array}$ & $\begin{array}{l}\text { Abstrak } \\
\text { Undang undang Nomor } 1 \text { Tahun } 1974 \text { pasal } 2 \text { ayat (2) sangat jelas } \\
\text { mengahruskan pencatatan perkawinan, namun kenyataan di kalangan } \\
\text { masyarakat masih terdapat perkawinan yang tidak di catatkan hal ini terbukti } \\
\text { dengan adanya sidang isbat nikah di indonesia seperti di pengadilan tinggi } \\
\text { agama Jawa timur telah mengabulkan perkara permohonan (voluntair) } \\
\text { sebesar } 679 \text { perkara yang dikabulkan sesuai dalam laporan kinerja Pengadilan } \\
\text { Tinggi Agama tahun 2019. Adapun permasalahan yang diangkat adalah } \\
\text { bagaimana implikasi isbath nikah terhadap status istri, anak dan harta } \\
\text { perkawinan dalam perkawinan dibawah tangan. Metode penelitian dalam } \\
\text { penulisan artikelnya ini adalah metode penelitian hukum normatif, yaitu } \\
\text { penelitian yang difokuskan untuk mengkaji penerapan kaidah-kaidah atau } \\
\text { norma-norma dalam hukum positif. Penelitian hukum yuridis normatif } \\
\text { metodenya biasanya bersifat kualitatif (tidak berbentuk angka). Dalam } \\
\text { temuannya bahwa implikasi isbath nikah terhadap status istri, anak dan harta } \\
\text { perkawinan dalam perkawinan dibawah tangan, bahwa dengan adanya isbat }\end{array}$ \\
\hline
\end{tabular}


nikah sesuai dengan Peraturan Mahkamah Agung Nomor 1 tahun 2015 memiliki akibat hukum apabila dilakukan permohonan pengesahan perkawinan yang berimplikasi jaminan hukum hubungan perkawinan suami dan istri, anak dan akte kelahirannya, harta dalam perkawinan dapat memperolah jaminan hukum.

Kata Kunci : isbath nikah; legalitas; status perkawinan.

\section{PENDAHULUAN}

Bahwa sangat jelas ketentuan dalam Undang Undang Nomor 1 Tahun 1974 pasal 2 ayat (2) bahwa dalam ketentuan pasal tersebut jelas mengharuskan sebuah pernikahan harus di "catat", namun banyak masyarakat menganggap hal itu biasa biasa aja, terindikasi masih adanya pernikahan yang tidak dicatatkan terutama dominasi wilayah kerja Pengadilan Agama $^{1}$ Pamekasan, Banyuwangi ${ }^{2}$, Trenggalek, Kabupaten Kediri, Situbondo, Kabupaten Madiun, Bondowoso, Sumenep, Pasuruan, Bojonegoro, sedangkan pola yang dilakukan oleh Pengadilan Agama adalah dengan melakukan kegiatan istbath nikah secara terpadu yang bekerjasama dengan instansi lain seperti Kantor kecamatan, Masjid, Kantor Desa, dan Dinas kependudukan dan Pencatatan Sipil. ${ }^{3}$

Di kalangan akademisi dan praktisi hukum khususnya hakim peradilan agama, masih bersilang pendapat pengertian yuridis sahnya suatu perkawinan. Pertama, kalangan akademisi dan praktisi hukum yang berpendapat bahwa sahnya suatu perkawinan semata-mata hanya harus memenuhi Pasal 2 ayat (1) Undang-Undang Perkawinan, yakni perkawinannya telah dilaksanakan menurut ketentuan syariat Islam secara sempurna (memenuhi rukun dan syarat nikah). Sedangkan pencatatan nikah oleh Pegawai Pencatat Nikah, tidaklah merupakan syarat sahnya nikah, tetapi hanya kewajiban administratif saja ${ }^{4}$. Kedua, kalangan akademisi dan praktisi hukum yang berpendapat bahwa sahnya suatu akad nikah manakala terpenuhinya ketentuan Undang-Undang Perkawinan Pasal 2 ayat (1) mengenai tatacara agama dan ayat (2) mengenai pencatatan nikah oleh PPN secara simultan. Dengan demikian, menurut kelompok ini, ketentuan Pasal 2 ayat (1) dan ayat (2) tersebut merupakan syarat kumulatif, bukan

\footnotetext{
${ }^{1}$ Pengadilan Tingga Agama Laporan Pelaksanaan Kegiatan Tahun 2019, Surabaya, 2019, hlm. 55. diakses tanggal 15 Agustus 2020

2 Bahwa dalam publikasi laporan tahunan Pengadilan Tinggi Agama Jawa Timur Kabupaten Banyuwangi menduduki tertinggi jumlah perkara isbath nikah sebesar 210 perkara, sedangan jumlah perkara secara keseluruhan yang dikabulkan di PTA Suarabaya terkait isbat nikah sebasar 769 perkara; Ibid, PTA, Laporan, hal 55

${ }^{3}$ Ibid, PTA, Laporan, hlm. 55

${ }^{4}$ Endang Ali Ma'sum, Kepastian Hukum 'Itsbat Nikah'Terhadap Status Perkawinan, Status Anak Dan Status Harta Perkawinan, https://bldk.mahkamahagung.go.id/id/puslitbang-hukum-dan-peradilan/dokkegiatan-litbangkumdil/531-kepastian-hukum-itsbat-nikah-terhadap-status-perkawinan-anak-dan-hartaperkawinanbanten.html Diakses 15 Agustus 2020
} 
alternatif. Oleh karena itu, perkawinan yang dilakukan sesuai ketentuan syariat Islam tanpa pencatatan oleh Pegawai Pencatat Nikah, belumlah dianggap sebagai perkawinan yang sah. ${ }^{5}$

Perkawinan yang tidak dicatatkan atau dalam bahasa masyarakat umum disebut dengan perkawinan sirri $^{6}$. Realita yang terjadi dalam masyarakat Islam sering terjadi praktek nika sirri atau kawin sirri. Dan oleh masyarakat, nikah ini dipandang sebagai perkawinan yang sah menurut agama (apabila terpenuhi syarat dan rukunnya). Padahal menurut ketentuan hukum yang berlaku bahwa perkawinan tersebut tidak memiliki kekuatan hukum ${ }^{7}$. Fenomena perkawinan dibawah tangan tidak dapat dipungkiri dan masih ada sampai saat ini, hal itu dibuktikan dengan masih terdapat isbath nikah dibeberapa pengadilan agama jawa timur yang mengabulkan perkara isbath nikah sebanyak 769 perkara isbat nikah. Perangkat hukum sangat jelas menyatakan keberadaanya, namun tidak menyurutkan untuk melakukan nikah dibawah tangan dan pernikahan (sirri) bagi masyarakat.

Ada beberapa alasan mengapa masyarakat masih melakukan pernikahan dibawah tangan, tiga alasan orang lebih memilih untuk nikah di bawah tangan: Pertama, untuk menghindari pembayaran biaya administrasi dan berbagai pungutan baik resmi maupun tidak resmi dari pencatatan perkawinan; Kedua, mencari barokah dari kiyai bagi pelaku perkawinan baik wali nikah maupun mempelai laki-laki dari kelompok 'santeri'; Ketiga, pernikahan dalam rangka poligami liar untuk menghilangkan jejak sehingga bebas dari tuntutan hukum dan hukuman administrasi dari instansinya bagi pegawai negeri sipil, dan agar tidak diketahui oleh isteri yang sudah ada terlebih dahulu dan menghindari ijin poligami yang harus diurus di pengadilan. ${ }^{8}$

Jikalau menikah sirri itu dengan alasan agar tidak diketahui sesuai dengan alasanalasan diatas, maka dalam sebuah referensi terdapat penjatuhan sanksi pidana karena zina/overspel seperti tertuang dalam amar putusan pengadilan negeri nomor 56/Pid.B/2014/PN.Sik tahun 2014 bahwa mereka dianggap bersalah karena di duga telah melakukan perzinahan yang telah memenuhi unsur pasal 284 (1) ke-1 huruf a dan ke-2 huruf b KUHP jo pasal 65 (1) KUHP bahwa meraka telah melakukan overspel walaupun mereka telah melakukan pernikahan secara sirri ( nikah yang tidak dilakukan pencatatan di registrasi

\footnotetext{
${ }_{6}^{5}$ Loc.cit, Endang Ali Ma'sum, Kepastian Hukum

${ }^{6}$ Andri, Mohammad., (2015), "Akibat Hukum Perkawinan Sirri Ditinjau Dari Hukum Islam Dan Undang-undang No. 1 Tahun 1974 Tentang Perkawinan." Justicia Journal, Vol. 4, No.1, hlm. 1-18.

7 Ibid, hlm.18. Lihat juga dalam Pasal 2 ayat (2) UU No. I/1974 dinyatakan bahwa "Tiap-tiap perkawinan dicatat menurut peraturan perundang-undangan yang berlaku.

${ }^{8}$ Op.cit, Endang Ali Ma'sum, Kepastian Hukum 'Itsbat Nikah';, kemudian lihat juga dalam artikel Andri, Mohammad, (2015), "Akibat Hukum Perkawinan Sirri Ditinjau Dari Hukum Islam Dan Undang-undang No. 1 Tahun 1974 Tentang Perkawinan." Justicia Journal, Vol. 4, No.1, hlm. 18.
} 
negara. Sehingga dalam majelis hakim menyatakan dalam putusannya bahwa kedua terpidana itu telah secara sah dan terbukti dan menyakinkan melakukan kesalahan berupa tindak pidana "perzinahan dan turutt serta melakukan perzinahan beberapa kali" yang mana terdakwa satu masih secara sah terikat perkawinan dengan istrinya. Sehingga dalam amar putusan majelis hakim menjatuhkan pidana penjara kepada masing-masing dengan penjara selama 4 bulan $^{9}$.

Bahwa dasar pemikirannya adalah karena perilaku mereka dianggap melanggar ketentuan yang terdapat dalam konsep pasal 2 ayat (2) UU No. 1 Tahun 1974 tentang perkawinan dan peraturan pemerintah nomor 9 tahun 1975 tentang tatacara perkawinan. Namun yang perlu di garisbawahi adalah selama pelaksanaan nikah dibawah tangan tersebut telah memenuhi rukun dan syarat-syarat pernikahan hal itu diperbolehkan dalam fiqh islam, karena ketentuan pencatatan bukan sebagai syarat sebuah sahnya pernikahan, namun hanya merupakan sebagai syarat administrasi negara sebagai wujud perlindungan hukum terjadinya pernikahan itu. Namun kenyataan dilapangan sampai saat ini masih ada pihak yang melakukan pernikahan dibawah tangan, padahal jaminan hukum tidak dapat diberikan dan lebih merugikan pihak istri, anak, dan terlebih harta dalam perkawinan. Pernikahan tidak hanya hubungan antara seorang laki-laki dan perempuan saja, namun lebih dari itu yaitu adanya penyatuan dua keluarga yang berbeda dan "bertujuan membangun keluarga sakinah mawaddah dan warahmah". ${ }^{10}$

\section{RUMUSAN MASALAH}

Berdasarkan latar belakang diatas penulis akan mengakaji beberapa objek permasalahan yang penulis anggap sebagai permasalahan yang cukup krusial yang penulis rumuskan yakni "bagaimana implikasi isbath nikah terhadap status istri, anak dan harta perkawinan dalam perkawinan dibawah tangan?".

\section{METODE PENELITIAN}

Dalam melakukan penelitian metode yang digunakan adalah metode penelitian hukum normatif, yaitu penelitian yang difokuskan untuk mengkaji penerapan kaidah-kaidah atau

${ }^{9}$ Hukumonline, “Apakah Nikah Siri Bisa Dijerat Pasal Perzinahan”, tersedia online di halaman https://www.hukumonline.com/klinik/detail/ulasan/lt5afd7b0bcf533/apakah-nikah-siri-bisa-dijerat-pasalperzinahan, diakses pada tanggal 15 Agustus 2020

${ }^{10}$ Bahwa" Perkawinan dalam nailai-nilai islam adalah menciptakan kedamaian, ketentraman, yang penuh dengan cinta dan kasih sayang dalam sebuah keluarga yang sakinah, mawaddah, dan warahmah, selain itu juga merupakan 'mistsaqon qhalidzan'" lihat dalam Andri, Muhammad, H. R. Mahmutarom, and Ahmad Khisni. (2020), "The Ideal Age of Marriage as an Effort to Establish an Ideal Family." UNIFIKASI: Jurnal Ilmu Hukum, Vol. 7, hlm. 70-78. 
norma-norma dalam hukum positif. Penelitian hukum yuridis normatif metodenya biasanya bersifat kualitatif (tidak berbentuk angka). ${ }^{11}$ Menurut Soetandyo Wignyosoebroto penelitian hukum normatif itu berusaha menginventarisasi hukum positif, dan berupaya menemukan asas-asas dan dasar falsafah (dogma atau doktrin) hukum positif. Adapun hal yang menjadi pokok kajian adalah terkait dengan bagaimana implikasi isbath nikah terhadap status istri, anak dan harta perkawinan dalam perkawinan dibawah tangan. Adapaun sifat dari penelitian ini adalah bersifat kualitatif, adalah penelitian yang mengacu pada norma-norma hukum yang terdapat dalam peraturan perundang-undangan dan putusan pengadilan serta norma-norma yang hidup dan berkembang dalam masyarakat. ${ }^{12}$

\section{PEMBAHASAN}

\section{Implikasi Isbath Nikah Terhadap Status Istri, Anak Dan Harta Perkawinan Dalam}

\section{Perkawinan Dibawah Tangan}

Menurut Majelis Ulama Indonesia dalam fatwa nya yang terdapat pada point ketentuan umum menyatakan bahwa pernikahan dibawah tangan yang dimaksud adalah pernikahan yang memenuhi syarat dan rukun sesuai ketentuan fiqh (hukum islam), namun pernikahan tersebut tidak dicatatkan dalam ketentuan undang-undang. ${ }^{13}$ Bahwa menurut MUI penyebutan nikah dibawah tangan dengan nikah sirri yang berkembang di masyarakat saat ini adalah untuk memberikan pandangan yang berbeda dalam pengertiannya, karena pernikahan dibawah tangan yang dimaksud adalah terpenuhinya syarat dan rukun islam. ${ }^{14}$

Bahwa nikah dibawah tangan yang tidak dicatatkan menurut MUI berimplikasi negatif atau madlarrah terhadap keberadaan isteri serta kedudukan anak-anak yang dilahirkan dari perkawinan tersebut. Karena secara yuridis mereka dianggap tidak melakukan perkawinan, mengapa demikian, karena dalam ketentuan undang-undang sangat jelas disebutkan bahwa perkawinan dianggap sah bila dilakukan sesuai dengan hukum masing-masing agamanya , lihat dalam pasal 2 ayat (1) undang-undang perkawinan, memang benar sah secara agama bila

\footnotetext{
11 Ibid,

${ }^{12}$ Andri, Muhammad. , (2020), "Implementasi Bimbingan Perkawinan Sebagai Bagian Dari Upaya Membangun Keluarga Muslim Yang Ideal." ADIL Indonesia Journal, Vol. 2, No. 2.

${ }^{13}$ Fatwa Majelis Ulama Indonesia Nomor 10 Tahun 2008 Tentang Nikah Di Bawah Tangan, diaksen melalui http://mui.or.id/wp-content/uploads/files/fatwa/45.-Nikah-di-bawah-tangan.pdf. diakses tanggal 15 Agustus 2020

${ }^{14}$ Nikah sirri yang sebenarnya adalah akad antara antara seorang lelaki dengan seorang perempuan tanpa wali dan tanpa hadirnya saksi. Kalau pengertian sirri itu dianggap hanya berdua saja, tanpa dilengkapi syarat dan rukun nikah lainnya, menurut KH. Ma'ruf Amin, bisa dipastikan pernikahan semacam ini tidak sah. Dalam fiqh konvensional, sejatinya tidak dikenal istilah 'nikah sirri', sedangkan padanan yang cocok bagi istilah 'nikah di bawah tangan' adalah nikah 'urfi. Loc.cit, Endang Ali Ma'sum, Kepastian Hukum.
} 
sesuai syarat dan rukunnya ${ }^{15}$, namun tidak hanya sah secara agama saja, akan tetapi perlu juga di sahkan sesuai dengan ketentuan undang undang seperti termaktub dalam pasal 2 ayat(2) undang-undang perkawinan., maka ketentuan ini sesuai dengan keputusan MUI pada point kedua: "Pernikahan harus dicatatkan secara resmi pada instansi berwenang, sebagai langkah preventif untuk menolak dampak negative/madharrat (saddan lidz-dzari'ah)".

Menurut Quraish Shihab mencatat, dikalangan semua ulama, sepakat tentang larangan merahasiakan perkawinan, berdasar perintah Nabi untuk menyebarluaskan berita perkawinan. $^{16}$ Adapun, perkawinan tanpa pencatatan (di bawah tangan), dalam konteks Indonesia, menurut Quraish Shihab, berpendapat bahwa pernikahan tidak dicatatkan dapat mengakibatkan dosa bagi pelakunya, karena melanggar ketentuan yang ditetapkan oleh pemerintah, dan DPR, sebagai ulil amri, padahal dalam konsep al-Qur'an memerintahkan untuk mematuhi (taat) kepada ulil amri selama tidak bertentangan dengan hukum-hukum Allah. Sementara perintah pencatatan perkawinan bukan hanya tidak bertentangan, tetapi sejalan dengan semangat al-Quran. ${ }^{17}$

Secara Legal Procedure pelaksanaan nikah dibawah tangan dapat dikatagorikan maladministrasi karena mengabaikan ketentuan dalam pasal 2 ayat 2 undang-undang perkawinan, sehingga meskipun dapat dikatakan sah secara hukum agama islam (fiqh islam) dan memenuhi syarat dan rukunnya namun tidak memenuhi ketentuan pencatatan yang merupakan sebuah peristiwa hukum (terjadinya pernikahan). Akibatnya perkawinan itu tidak memiliki berimplikasi hukum pada status perkawinan sah dan tercatat di adaministrasi negara.

Segala sesuatu yang dilakukan tanpa adanya bukti outentic sebuah peristiwa hukum. Maka akibat hukum dari adanya hal-hal dari perkawinan di bawah tangan yang tidak dicatatkan pada Pegawai Pencatat Nikah, maka salah satu akibatnya adalah: Pertama, bahwa meskipun perkawinan tersebut dilakukan menurut agama dan kepercayaan, namun di mata negara perkawinan tersebut dianggap tidak sah jika belum dicatat oleh Kantor Urusan Agama atau Kantor Catatan Sipil. Kedua, anak hanya mempunyai hubungan perdata dengan ibu dan keluarga ibu. Anak-anak yang dilahirkan di luar perkawinan atau perkawinan yang tidak tercatat, selain dianggap anak tidak sah, juga hanya mempunyai hubungan perdata dengan ibu

15 Dalam fatwa MUI “ Nikah Di Bawah Tangan yang dimaksud dalam fatwa ini adalah "Pernikahan yang terpenuhi semua rukun dan syarat yang ditetapkan dalam fiqh (hukum Islam) namun tanpa pencatatan resmi di instansi berwenang sebagaimana diatur dalam peraturan perundang-undangan". Lihat dalam keputusan majelis ulama indonesia Fatwa Majelis Ulama Indonesia Nomor 10 Tahun 2008 Tentang Nikah Di Bawah Tangan, diaksen melalui http://mui.or.id/wp-content/uploads/files/fatwa/45.-Nikah-di-bawah-tangan.pdf. diakses tanggal 15 Agustus 2020

${ }^{16}$ M. Quraish Shihab, (1996), Wawasan Al-Quran: Tafsir Maudhu'i atas Pelbagai Persoalan Ummat Bandung: Mizan, hlm. 204.

${ }^{17}$ Ibid., hlm. 204. 
atau keluarga ibu (Pasal 42 dan 43 Undang-Undang Perkawinan). Sedang hubungan perdata dengan ayahnya tidak ada. Ketiga, baik anak maupun ibunya tidak berhak atas nafkah dan warisan. Akibatnya, baik isteri maupun anak-anak yang dilahirkan dari perkawinan tersebut, tidak berhak menuntut nafkah ataupun warisan dari ayahnya. Harta yang didapat dalam perkawinan di bawah tangan hanya dimiliki oleh masing-masing yang menghasilkannya, karena tidak adanya harta bersama.

\section{Dasar Hukum Adanya Pencatatan Perkawinan}

Bahawa pencatatan perkawinan merupakan upaya tertib administrasi sebagai bukti adanya peristiwa hukum, selain itu pencatatan perkwinan juga dapat dikatakan sebagai jaring pengaman terhadap perkawinan mereka. Selain terdapat Peraturan Mahkamah Agung Perma No 1 tahun 2015 "Tentang Pelayanan Terpadu Sidang Keliling Pengadilan Negeri Dan Pengadilan Agama/Mahkamah Syar'iyah Dalam Rangka Penerbitan Akta Perkawinan, Buku Nikah, Dan Akta Kelahiran". Dalam peraturan dapat ditemui beberapa aturan sebagai landasan hukum adanya pencatatan perkawinan, landasan itu diantaranya adalah:

Pertama, Undang-Undang Nomor 32 Tahun 1954 yang memberlakukan UndangUndang Nomor 22 Tahun 1946 tentang Pencatatan Nikah, Talak dan Rujuk. Kedua, UndangUndang Nomor 1 Tahun 1974 tentang Perkawinan (Pasal 2 ayat (2)). Ketiga, Peraturan Pemerintah Nomor 9 Tahun 1975 tentang Pelaksanaan Undang-Undang Nomor 1 Tahun 1974 (Pasal 2 s.d Pasal 9). Keempat, Instruksi Presiden Nomor 1 Tahun 1991 tentang Kompilasi Hukum Islam di Indonesia (Pasal 5, 6 dan 7). ${ }^{18}$

Permasalahan yang berkembang dimasyarakat secara sosiologis masih memegang tradisi tidak mencatatkan pernikahan itu, ada sebagaian masyarakat yang enggan mencatatkan itu karena berbagai faktor sehingga masyarakat dapat menyebut perkawinan semacam ini dengan berbagai sebutan, contoh sirri, kawin lari, perkawinan dibawah tanga. Melihat kenyataa demikian maka pemerintah memberikan pelayanan tentang isbath nikah sangat penting dilakukan oleh mereka yang melakukan perkawinan dibawah tangan. Sehingga pemerintah dapat memberikan jaminan hukum terhadap status perkawinan itu yang memiliki implikasi hukum bagi kedua pihak, anak, dan harta perkawinan.

\footnotetext{
${ }^{18}$ Suparman Usman, Kepastian Hukum Itsbat Nikah Terhadap Status Perkawinan, Status Anak dan Status Harta Perkawinan, Disampaikan dalam acara "Penelitian dan Pengkajian Aspek Hukum Itsbat Nikah" yang diselenggarakan oleh Mahkamah Agung pada tanggal 14-16 Mei 2012, bertempat di Hotel Le Dian Serang, Banten.
} 


\section{Alasan Permohonan Isbth Nikah}

Kwtika seseorang melakukan pernikahan dibawah tangan mengalami permasalahan yang ada kaitannya dengan syarat adminsitrasi kependudukan, dan syarat untuk keperluan administrasi sekolah anak, maka, dapat dipastikan akan mengalami kendala pemenuhan berkas administrasinya, hal semacam ini kerap terjadi karena unsur keterpaksaan pengurusan berkas itu, dan untuk kepentingan anak, sehingga memerlukan pengesahan status penrikahannya. Dalam mengajukan permohonan pencatatan nikahnya maka para pihak harus mengurus ke pengadilan agama setempat.

Permohonan isbath nikah adalah sebuah keharusan yang dilakukan pelaku perkawinan dibawah tangan. Doktrin pencatatan dalam setiap perbuatan sesuai ajaran islam yang senantiasa harus mencatatkan dalam bermuamalah transaksi hutang piutang seperti dalam (QS: 2: 282). Dalam islam juga harus ada walimah dalam pernikahan, tujuan dan alasannya adalah agar menjauhkan dari fitnah, begitu juga dengan pernikahan seyogyanya harus dicatatkan. Karena isbath nikah diperuntukkan bagi pernikahan dibawah tangan. Hal ini sangat bertangan dengan islam yang mengharuskan untuk meniklankan dalam pernikahannya. Sehingga masyarakat menjadi tahu dan menjamin keberlangsungan hubungan pernikahan itu.

Bahwa ketika permohonan itsbat nikah diajukan ke Pengadilan Agama dengan berbagai alasan di antaranya: 1) Itsbat nikah untuk melengkapi persyaratan akta kelahiran anak; 2) Itsbat nikah untuk melakukan perceraian secara resmi di pengadilan; 3) Itsbat nikah untuk mendapatkan pensiunan janda; 4) Itsbat nikah isteri poligami $;{ }^{19}$ maka dengan alasan tersebut isbath nikah dapat diajukan ke pengadilan agama. Setidaknya terdapat dua alasan pengadilan agama dapat menerima dan memutus perkara itsbat nikah terhadap perkawinan pasca berlakunya Undang-Undang Perkawinan ${ }^{20}$. Pertama, berkaitan dengan asas ius curia novit yakni hakim dianggap mengetehui hukum itsbat nikah, dan asas kebebasan Hakim untuk menemukan hukumnya terhadap masalah atau kasus yang tidak terdapat peraturan hukumnya (rechtsvacuum). ${ }^{21}$ Kedua, pendekatan sosiologis yang mendorong hakim menganalisis suatu kasus dengan pendekatan sosiologi hukum dan melakukan penafsiran baru

${ }^{19}$ Op.cit, Endang Ali Ma'sum, Kepastian Hukum 'Itsbat Nikah'

${ }^{20}$ Ibid.

${ }^{21}$ Pertama, Pasal 10 Undang-undang No 48 Tahun 2009 tentang kekuasaan kehakiman, "Pengadilan dilarang menolak untuk memeriksa, mengadili, dan memutus suatu perkara yang diajukan dengan dalih bahwa hukum tidak ada atau kurang jelas, melainkan wajib untuk memeriksa dan mengadilinya, kedua, pasal 5 Undang-undang No 48 tahun 2009 tentang Kekuasaan kehakiman "Hakim dan hakim konstitusi wajib menggali, mengikuti,dan memahami nilai-nilai hukum dan rasa keadilan yang hidup dalam masyarakat." Ketiga, Pasal 56 Ayat 1 Undang-Undang Nomor 3 Tahun 2006 tentang Perubahan atas Undang-Undang Nomor 7 Tahun 1989 tentang Peradilan Agama, berbunyi: "Pengadilan tidak boleh menolak untuk memeriksa dan memutus suatu perkara yang diajukan dengan dalih bahwa hukum tidak atau kurang jelas, melainkan wajib memeriksa dan memutusnya;", 
terhadap peraturan lain yang ada hubungannya dengan masalah yang dihadapi supaya hukum tidak stagnan, melainkan berkembang mengikuti perkembangan masyarakat seperti yang dikemukakan oleh Ibnu al-Qayyim al-Jauziyah bahwa hukum itu berubah karena ada perubahan, waktu, tempat, keadaan, adat istiadat. ${ }^{22}$ Langkah-langkah ini kemudian dikenal dengan sebutan penemuan hukum (rechtsvinding).

Setidaknya ada tiga karateristik yang sesuai dengan penemuan hukum yang progresif: pertama, Metode penemuan hukum bersifat visioner dengan melihat permasalah hukum tersebut untuk kepentingan jangka panjang ke depan dengan melihat case by case; kedua, Metode penemuan hukum yang berani dalam melakukan terobosan (rule breaking) dengan melihat dinamika masyarakat, tetapi tetap berpedoman pada hukum, kebenaran, dan keadilan serta memihak dan peka pada nasib dan keadaan bangsa dan negaranya; ketiga, Metode penemuan hukum yang dapat menbawa kesejahteran dan kemakmuran masyarakat dan juga membawa bangsa dan Negara keluar dari keterpurukan dan ketidakstabilan sosial seperti saat ini. $^{23}$ Sedangkan fungsi dari Pengadilan Agama adalah dapat menerima perkara permohonan itsbat nikah untuk keperluan Akta Kelahiran Anak yang belum memiliki akta, meskipun berusia lebih dari satu tahun dengan merujuk pada ketentuan yang bterdapat dalam Undang undang tentang Administrasi Kependudukan ${ }^{24}$.

Maka dalam implementasinya Mahkamah Agung telah mengeluarkan Perma nomor 1 tahun 2015 tentang pelayanan terpadu sidang keliling Pengadilan Negeri dan Pengadilan Agama $^{25}$ yang bertujuan untuk melayani masyarakat dalam memperoleh kepasian hukum, terkait dengan pengesahan perkawinan ${ }^{26}$ yang tidak tercatat bagi seorang bukan beragama islam dapat mengajukan pada pengadilan negeri yang telah memiliki pelayanan terpadu terkait dengan pengesahan perkawinan sesuai dengan pasal 2 point (b) perma no 1 tahun 2015

${ }^{22}$ Ibnu al-Qayyim al-Jauziyah, I'lam al-Muwaqi'in, Bairut: Dar al-Fikr, Juz, VII, 1397H/1977M, hlm. 14-15, dalam Op.cit, Endang Ali Ma'sum, Kepastian Hukum 'Itsbat Nikah'

23 Ahmad Rifai, (2010), Penemuan Hukum oleh Hakim dalam Perpektif Hukum Progresif, Jakarta: Sinar Grafika, Cet. I, hlm. 93 dalam Loc.cit, Endang Ali Ma'sum, Kepastian Hukum 'Itsbat Nikah'

${ }^{24}$ Pasal 32 ayat (2) Undang-Undang Nomor 23 Tahun 2006 tentang Administrasi Kependudukan yang menyatakan "bahwa pencatatan kelahiran yang melampaui batas waktu satu tahun dilaksanakan berdasarkan penetapan pengadilan yang menyatakan anak itu anak orangtua yang bersangkutan"

${ }_{25}$ Dalam pasal 1 ayat (1) Perma Nomor 1 Tahun 2015 menyebutkan "Pelayanan Terpadu Sidang Keliling yang selanjutnya disebut Pelayanan Terpadu adalab rangkaian kegiatan yang dila.kukan sccara bersama-sama dan terkoordinasi dalam satu waktu dan tempat tcrtentu antara Pengadilan Negeri atau Pengadilan Agama/ Mahkamah Syar'iyah, Dinas Kependudukan dan Pencatatan Sipil Kabupaten/Kota, Kantor Urusan Agama Kecamatan, dalam layanan keliling untuk memberikan pelayanan pengesahan perkawinan dan perkara lainnya scsuai dengan kewenangan Pengadilan Negeri dan itsbat nikah sesuai dengan kewenangan Pengadilan Agama/Mahkamah Syar'iyah dan untuk memenuhi pencatatan perkawinan dan pencatatan kelahiran."

${ }^{26}$ Dalam Pasal 1 ayat (2) perma No 1 tahun 2015 menyatakan "Pengesahan Perkawinan adalah pengesahan kawin bagi masyarakat beragama selain Islam yang dilakukan oleh Pengadilan Negeri sesuai dengan ketentuan yang berlaku". 
menyatakan bahwa salah satu tujuannya adalah "Membantu masyarakat terutama yang tidak mampu dalam memperoleh hak atas akta perkawinan, buku nikah, dan akta kelahiran yang dilakukan dengan sederhana, cepat dan biaya ringan"

Bagi Masyarakat penerima manfaat adanya prograam terpadu dari pengadilan ini dapat mengajukan permohonan ( voluntair) yang berkaitan dengan masalah hukum dalam perkawinan seperti yang tersebut dalam pasal 4 perma nomor 1 tahun 2015 menyatakan "anggota masyarakat yang pernikahannya atau kelahirannya belum dicatatkan;" sehingga manfaat ini sangat penting bagi masyarakat yang kurang mampu untuk mendapatkan leagalitas dalam hubungan perkaawinannya, akta anak, dan harta yang diperoleh dalam perkawinan sehingga memiliki implikasi hukum bagi semua yang berkempatingan dan menjamin bagi istri dan anak yang dilahirkan dari perkawinan dibawah tangan.

\section{PENUTUP}

\section{Kesimpulan}

Bahwa adanya peristiwa perkawinan dibawah tangan merupakan sebuah wujud mbalelo-nya masyarakat terhadap perilaku yang dilakukan secara diam-diam dan sembunyi sembunyi terhadap perkawinannya dimana yang seharusnya dilakukan pencatatan secara administratif namun tidak dilakukan pencatatan. Bahwa Itsbat Nikah adalah merupakan legalitas dan pengesahan nikah bagi masyarakat beragama Islam yang dilakukan oleh Pengadilan Agama/Mahkamah Syar'iyah sesuai dengan ketentuan yang berlaku. Sedangan bagi masyarakat yang beragama selain islam dapat melakukan pengesahan yaitu merupakan proses legalisasi Pengesahan Perkawinan bagi masyarakat beragama selain Islam yang dilakukan oleh Pengadilan Negeri sesuai dengan ketentuan yang berlaku. Sebagai wujud kepedulian Mahkamah Agung memberikan pelayanan terpadu bagi masyarakat umum, sehingga hubungan perkawinan yang tidak tercatat dapat memiliki implikasi hukum bagi semuanya baik itu untuk suami dan istri, juga untuk akta anak, dan juga keberadaan harta perkawinan dapat memperoleh kepastian hukum.

\section{Saran}

1. Perlu dilakukan edukasi untuk masyarakat tentang pentingnya pernikahan yang sesuai dengan ketentuan agama dan negara, sebagai jaring pengaman adanya hubungan yang sakral itu, yaitu dengan mencatatkan setiap adanya perkawinan, sehingga dapat berdampak bagi kedudukan hubungan itu dan anak yang dilahirkan yang sah. 
2. Disamping itu pentingnya meningkatkan kesejahteraan masyarakat, karena faktor ekonomi menjadi alasan meningkatnya faktor perkawinan tidak dicatatkan dengan alasan faktor ketiadaan uang.

\section{DAFTAR PUSTAKA}

Ahmad Rifai, (2010), Penemuan Hukum oleh Hakim dalam Perpektif Hukum Progresif, Jakarta: Sinar Grafika, Cet. I, hlm. 93

Ibnu al-Qayyim al-Jauziyah, I'lam al-Muwaqi'in, Bairut: Dar al-Fikr, Juz VII, 1397H/1977M, hlm. 14-15,

Endang Ali Ma'sum, Kepastian Hukum 'Itsbat Nikah' Terhadap Status Perkawinan, Status Anak Dan Hatus Herkawinan, https://bldk.mahkamahagung.go.id/id/puslitbang-hukum-dan-peradilan/dokkegiatan-litbangkumdil/531-kepastian-hukum-itsbat-nikah-terhadap-statusperkawinan-anak-dan-harta-perkawinanbanten.html Diakses 15 Agustus 2020

Andri, Mohammad. (2015) "Akibat Hukum Perkawinan Sirri Ditinjau Dari Hukum Islam Dan Undang-undang No. 1 Tahun 1974 Tentang Perkawinan." Justicia Journal 4.1: 18-18.

Andri, Muhammad, H. R. Mahmutarom, and Ahmad Khisni. (2020), "The Ideal Age of Marriage as an Effort to Establish an Ideal Family." UNIFIKASI: Jurnal Ilmu Hukum 7.1: 70-78.

Andri, Muhammad. (2020). "Implementasi Bimbingan Perkawinan Sebagai Bagian Dari Upaya Membangun Keluarga Muslim Yang Ideal." ADIL Indonesia Journal 2.2.

Suparman Usman, (2012), Kepastian Hukum Itsbat Nikah Terhadap Status Perkawinan, Status Anak dan Status Harta Perkawinan, Disampaikan dalam acara "Penelitian dan Pengkajian Aspek Hukum Itsbat Nikah" yang diselenggarakan oleh Mahkamah Agung pada tanggal 14-16 Mei 2012, bertempat di Hotel Le Dian Serang, Banten.

M. Quraish Shihab, (1996), Wawasan al-Quran: Tafsir Maudhu 'i atas Pelbagai Persoalan Ummat, Bandung: Mizan.

\section{Undang-Undang}

Undang-undang No. 1 tahun 1974 tentang perkawinan

Undang-undan No. 48 tahun 2009 tentang kekuasan kehakiman

Undang-undan No. 3 tahun 2006 tentang Peradilan Agama. 
Undang-Undang Nomor 23 Tahun 2006 tentang Administrasi Kependudukan

Peraturn Mahkamah Agung Nomor 1 Tahun 2015 Tentang Pelayanan Terpadu Sidang Keliling Pengadilan Negeri Dan Pengadilan Agama/Mahkamah Syar'iyah Dalam Rangka Penerbitan Akta Perkawinan, Buku Nikah, Dan Akta Kelahiran

\section{Internet}

Pengadilan Tingga Agama Laporan Pelaksanaan Kegiatan Tahun 2019, Surabaya, 2019, hal 55. diakses tanggal 15 Agustus 2020

https://www.hukumonline.com/klinik/detail/ulasan/lt5afd7bObcf533/apakah-nikah-siri-bisadijerat-pasal-perzinahan, diakses pada tanggal 15 Agustus 2020

Fatwa Majelis Ulama Indonesia Nomor 10 Tahun 2008 Tentang Nikah Di Bawah Tangan, diaksen melalui http://mui.or.id/wp-content/uploads/files/fatwa/45.-Nikah-dibawah-tangan.pdf. Diakses tanggal 15 Agustus 2020. 